Genetic constraints on post-glacial boreal tree expansion

\title{
1 Constraints on post-glacial boreal tree expansion out of far-northern
}

\section{2 refugia}

3

4 Mary E. Edwards 1,2 *

5 W. Scott Armbruster $3,4,5$

6 Scott E. Elias ${ }^{6}$

7

$8{ }^{1}$ Geography and Environment, University of Southampton, Highfield, Southampton, SO1 $9 \quad 1 \mathrm{BJ}, \mathrm{UK}$

$10{ }^{2}$ Alaska Quaternary Center, University of Alaska, Fairbanks, AK 99775, USA

$11{ }^{3}$ School of Biological Sciences, University of Portsmouth, Portsmouth PO1-2DY, UK

$12{ }^{4}$ Institute of Arctic Biology, University of Alaska, Fairbanks, AK 99775, USA

$13{ }^{5}$ Department of Biology, NTNU, NO-7491 Trondheim, Norway

$14{ }^{6}$ Geography Department, Royal Holloway, University of London, Egham, Surrey TW20

$15 \quad$ OEX

$16 *$ Corresponding author

17 
Genetic constraints on post-glacial boreal tree expansion

\section{ABSTRACT}

19 Aim To use a variety of data sources to infer how northern boreal trees recovered their range upon deglaciation and/or Holocene warming.

21 Location Scandinavia, Alaska/north-west Canada (eastern Beringia).

22 Methods Mapped fossil occurrences for Picea (spruce) assessed against available

23 palaeoenvironmental and phylogeographic information.

24 Results Scandinavia - Last glacial maximum (LGM) evidence of Picea is confined to one DNA record, but late-glacial and early-Holocene records include scattered macrofossils.

Holocene pollen data show a clear east-west increase to high values. A haplotype unique to the Scandinavian Peninsula is recognised.

Eastern Beringia — Pre- and post-LGM macrofossils occur, but the LGM fossil record comprises only scattered low pollen values. Early-Holocene pollen values increase markedly $\sim 11$ cal yr BP (NW Canada) and $\sim 10 \mathrm{kcal} \mathrm{yr} \mathrm{BP} \mathrm{(central} \mathrm{Alaska).} \mathrm{Also} \mathrm{at} \mathrm{this} \mathrm{time} \mathrm{three} \mathrm{sites}$ on the Bering Land Bridge indicate presence of Picea where it is now absent. Several unique regional haplotypes are recorded; while most are rare, one is common in some modern populations.

Main conclusions Small Picea populations probably occurred in pre-Holocene Scandinavia, but pollen patterns argue against immediate expansion with the onset of warmer conditions. Despite relatively weak fossil evidence, refugial populations are also probable in eastern

37 Beringia, particularly given the extent of unglaciated terrain. Post-glacial pollen patterns are more nuanced, suggesting two spatially and temporally distinct expansions, one possibly consistent with a unique central Alaskan haplotype, and subsequent westerly "filling-in". The presence of macrofossils and/or neutral markers does not require that current northern populations are derived primarily from refugial ones, particularly where pollen patterns show 
Genetic constraints on post-glacial boreal tree expansion

42 delayed directional expansion of large populations though time. Refugial populations initially

43 responded weakly to major post-glacial environmental change; if subject to genetic isolation

44 and strong selection pressure they may have had little potential to do otherwise, instead being

45 largely replaced by in-migrating populations with greater genetic diversity.

46

47

48

49 KEY WORDS: Refugial population, relictual population, Picea, evolution, climate change, 50 Scandinavia, Alaska, eastern Beringia, Late Quaternary 
Genetic constraints on post-glacial boreal tree expansion

\section{INTRODUCTION}

The role of northern refugia as sources of post-glacial recolonization is highly topical (Stewart et al., 2009; Tzedakis et al., 2013); it has triggered a potential shift of emphasis from long-distance migration to in-situ expansion in determining spatial responses of species to climate change. Survival and expansion of species from small northern refugia may alter our views of how recolonization of space occurs, and also ideas about rates at which species can disperse over landscapes. This in turn affects the operation of niche models and other projections of response to future climate change (Birks \& Willis, 2008; Svenning et al., 2008). The fates of refugial populations undoubtedly unfold differently depending upon the life-history of the organism: small mammals have vastly different life histories than trees, for example. Trees, however, are an important long-term study system because of the abundant fossil record for many species, and because their history is often used as a model for biogeographic thinking (e.g. Mclachlan et al., 2005; Magri, 2008), and it is tree-species refugia we address here.

Good palaeoecological records of late-Quaternary tree species exist in Europe and North America. Continental-scale, directional, time-transgressive increases of forest tree pollen to relatively high values (values are taxon-dependent) are usually interpreted as migration of a large population from a distant region (e.g., Davis, 1981; Giesecke \& Bennett, 2004) and comprise two linked processes: the dispersal of individuals into new spaces (and establishment of small founder populations), and population expansion, typically signifying the achievement of a dominant role in forest composition (Giesecke 2005a). On the other hand, persistent, low pollen values could be due to long-range pollen transport or to small local populations, and they are ambiguous without other information (Brubaker et al., 2005). Macrofossils (wood, needles) provide clear evidence of presence of trees, but their generally sporadic and localized occurrence says little about population size. A key question is the 
Genetic constraints on post-glacial boreal tree expansion

extent to which refugial populations later expanded with climatic amelioration, as opposed to being overtaken by larger in-migrating populations. An examination of macrofossil finds in the context of large-scale pollen patterns can address this question.

While it is acknowledged that a range of ecological and genetic constraints to survival and expansion may be experienced by contemporary small populations and founder populations (Lande, 1988; Geisecke, 2005a), there currently seems to be quite broad acceptance that Pleistocene refugial populations can be transformed into widespread Holocene forest cover - that is, presence alone somehow assures later expansion (e.g., Feurdean et al., 2013). The concept of a biological "refugium" implies the ability of refugial species to expand at a later time, but various properties of a population can compromise that ability (rendering the population an extinction-prone "relict"). Recently, properties such as demographic status and evolutionary trajectory have been discussed by Bennett \& Provan (2008) and Hampe \& Jump (2011); Hampe \& Petit (2005) and Davis et al., (2005) have pointed out the important role of evolution in the migration of large populations. These considerations deserve further attention, given the increasing focus on refugia.

In this study we explore the palaeoecological evidence for small refugial (or relictual) populations and large-scale migration of the genus Picea (spruce) using a comparative approach in two contrasting sub-continental regions, and we discuss the likely evolutionary implications of observed patterns. Picea is a widespread genus, being dominant in the boreal forest of both northern Europe and northern North America and featuring in a large number of palaeoecological records. The patterns of post-glacial spruce colonization to its northwestern limits in both regions (Scandinavia and Alaska-northwest Canada [eastern Beringia], respectively), as shown by broad-scale pollen mapping (e.g., Giesecke \& Bennett 2004; Brubaker et al., 2005, respectively), occurred over many millennia. The glacial histories of the two regions are strikingly different, however, Scandinavia having been widely glaciated 
Genetic constraints on post-glacial boreal tree expansion

101 while large portions of northern and central eastern Beringia remained ice-free. Here we compare the pollen and macrofossil patterns that are now available for both regions, taking

103 into account data on neutral genetic markers. Through a consideration of the major

104 environmental changes occurring with global deglaciation and the evolutionary processes

105 affecting both small, isolated populations in sub-optimal habitats and large-scale in-

106 migration, we present a conceptual model that attempts to reconcile current data.

107

108 Geographic regions, study species and late-Quaternary history

109 Scandinavia (P. abies [L.]Karst.)

110 Nomenclature follows the Integrated Taxonomic Information System (www.itis.gov). Dates

111 and ages are reported as calibrated radiocarbon years before present unless otherwise

112 indicated. Today boreal forest covers much of the Scandinavian Peninsula except alpine

113 areas. A strong W-E gradient of increasing continentality influences vegetation composition.

114 Picea abies prefers high-nutrient, moist soils, and its current range limits coincide with

115 January mean temperatures of less than $-1.0^{\circ} \mathrm{C}$ (Giesecke \& Bennett 2004). Its range

116 extends from NW Scandinavia to the mountains of central Europe and eastward to Russia.

117 Spruce populations were present during Marine Isotope Stage (MIS) 3 (which began

$118>50 \mathrm{kyr}$ BP and ended at the LGM) in ice-free areas of the Scandinavian Peninsula (Helmens

119 \& Engels, 2010). Scandinavia was extensively glaciated during the last glacial maximum

120 (LGM; informally used here as $\sim 25-15 \mathrm{kyr}$ BP to fit Beringian climate history). A few areas

121 remained intermittently ice-free and mountain tops likely became ice-free early (Wohlfarth $e t$

122 al.., 2008; Giesecke 2005b and references therein). In-situ survival and/or colonization

123 during the Late Glacial/LGM is argued from two dated macrofossil finds (see Table 1) and

124 from other less secure data: a Picea stoma dated indirectly to >11 ka from central Norway 
Genetic constraints on post-glacial boreal tree expansion

125 (Paus et al.., 2011), and cpDNA identified as Picea from lake sediments dated to $17.7 \mathrm{ka}$ in northwest Norway (Parducci et al.., 2012a). Rapid deglaciation occurred, being complete by 9-7 kyr BP (Wohlfarth et al.., 2008). Pollen maps show northern regions of Europe were colonized from the south and east during the Holocene; the Scandinavian Peninsula was possibly colonized via east-west (trans-

130 Baltic) and northern routes (Giesecke \& Bennett, 2004); high values of Picea pollen are only achieved in the mid to late Holocene over much of the region (Fig. 1). In contrast, Kullman (2002, 2008) and Oberg and Kullman (2011, and references therein) report finds of fossil wood across Scandinavia, the oldest of late-glacial age, but most of early-Holocene age

134 (Table 1).

Genetically, there is a deep split between northern (Russian-Scandinavian) and central 136 European spruce populations (Tollesfrud et al., 2008). From a comparison of microsatellite and mtDNA data, Tollesfrud et al., (2009) conclude that individuals derived from the northern European population entered Scandinavia via both a southern (trans-Baltic) and a northern (north Finland) route, which is mirrored in the pollen-based Holocene migration

140 patterns (Fig. 1; Giesecke \& Bennett, 2004). A widespread northern haplotype occurs throughout the range and is present east and south of the Baltic, whereas a more localized haplotype occurs only in western Scandinavia. Intriguingly, this haplotype is present in

143 pollen dated to $\sim 6 \mathrm{ka} \mathrm{BP}$ from a lake in central Norway, near to one of the documented finds

144 of early-Holocene spruce wood (Parducci et al., 2012a). Of the two sub-continental regions,

145 Scandinavia was far more heavily and extensively glaciated, and yet early-Holocene finds of 146 spruce (and other tree) macrofossil material are quite widely reported. This is, perhaps, one

147 reason for the more heated discussion surrounding spruce survival in Scandinavia (e.g.,

148 Kullman, 2002; Birks et al.., 2005; Geisecke, 2005b) than in unglaciated northwest North 149 America 
Genetic constraints on post-glacial boreal tree expansion

151 Eastern Beringia (Picea glauca [Moench] Voss and P. mariana [Mill.] Britton, Sterns and

152 Poggenb)

153 Eastern Beringia is characterized by a cold continental climate, and the western coastal zone

154 is markedly less maritime than equivalent latitudes in Norway. Boreal forest in eastern

155 Beringia mainly lies between the southern Cordillera and the northern Brooks Range and its eastward extensions. It is dominated by Picea glauca (white spruce) and P. mariana (black spruce). Both species have continuous ranges east to the Atlantic seaboard. Picea glauca tends to occupy warmer, better-drained parts of the landscape. Growth within parts of its current range is limited by low summer moisture levels (Barber et al., 2000). Most records

160 indicate that $P$. glauca was the first species to expand in the region during the Holocene, and 161 it is usually the treeline species today. Picea mariana became widely established in the mid Holocene 5-8 kyr ago (Anderson et al., 2004).

164 Beringia was a long phase during which warmth and moisture levels were intermediate

165 between LGM and interglacial conditions (Hopkins, 1982). LGM conditions were dry and the vegetation largely treeless (Hopkins 1982; Anderson et al., 2004). Lower sea levels exposed the continental shelves of the Bering and Chukchi Seas and linked Alaska with eastern Siberia. The Cordilleran and Laurentide Ice Sheets isolated eastern Beringia from the rest of unglaciated North America. Exactly when the "ice-free corridor" opened as the

170 Laurentide and Cordilleran ice sheets parted is still a matter of some conjecture: it probably opened between 13.5 and 12.5 kyr BP (Dyke, 2004). Strong summer warming occurred in the Late Glacial and early Holocene (Kaufman et al., 2004) and in eastern areas the late-glacial period was characterized by low levels of effective moisture (Barber \& Finney 2000). Post-

174 glacial sea-level rise subsequently severed the land connection and restored the Bering Strait. 
Genetic constraints on post-glacial boreal tree expansion

175

176

177

178

179

180

181

182

183

184

185

186

187

188

189

190 METHODS

191

192

193

194

195

196

197

198

199

The history of boreal forest taxa has been studied less intensively than in Scandinavia, partly due to the large size and inaccessibility of the region. Macrofossil finds of boreal tree taxa are relatively rare (Hopkins et al., 1981), and a lack of macrofossils from LGM time led initially to the assumption that Picea was eliminated from the region. This view is starting to change as more data have become available (see below).

A survey of modern cpDNA variation in Alaskan P. glauca by Anderson et al., (2006) showed high variation, the authors arguing for the presence of refugial populations that may have been largely undetected palaeoecologically (i.e., cryptic refugia).

Subsequently, using microsatellites to reassess the patterns, Anderson et al., (2011) found evidence of likely refugial populations, possibly focussed in north-central Alaska, and one haplotype prominent in modern populations in this area. They interpret genetic patterns as indicating mixing and bidirectional gene flow towards and from the east, but they also detected lower heterozygosity levels in Alaskan populations and conclude that inbreeding and bottlenecks may have occurred.

\section{Mapping of eastern Beringia fossil data}

In order to compare North American patterns with those already established for Scandinavia, we synthesized spatio-temporal patterns for spruce in eastern Beringia in ARC-GIS using the pollen threshold approach of Giesecke \& Bennett (2004) for Scandinavia (see below). We used 71 dated pollen records collated from public databases plus 20 records either digitized from published data or taken from our own unpublished sites (Table S1). Only samples dated to $\leq 15,000$ yr BP were used, and sites with only one reported sample were omitted (see Table S-1). Most records had calibrated radiocarbon ages. Radiocarbon date calibration approaches vary among authors, but not to the extent that emergent patterns would be significantly 
Genetic constraints on post-glacial boreal tree expansion

200 affected in 1000-yr time-slices. To calibrate other records, typically single dates on

201 macrofossils, we used CalPal-2007online (Danzeglocke et al., 2013). Where sites in the

202 database were older studies (pre-AMS dating) and had been re-studied with an AMS

203 chronology we used the newer study (Table S-1).

204 Threshold maps were made for the first occurrence of Picea pollen at the 1,5 and

$20510 \%$ levels and pollen-percent. A threshold was crossed or a contour value attained if one or 206 more samples in a time-slice had the appropriate pollen value. Shapefiles for eastern Beringia

207 (coordinate system UTM Zone 6N) included site locations for Picea values from 15,000 yr

208 BP-present. We mapped percent pollen values using Inverse Distance Weighting (IDW) tool

209 in Arc-GIS to create a raster surface in exactly the same manner as Geisecke and Bennett

210 (2004). A treeline shapefile was created by georeferencing an existing map representation of

211 the treeline and digitising the outline.

212 The threshold algorithm has limitations when applied to eastern Beringia data.

213 Records show that in NW Canada the treeline advanced and then retreated, and at other sites

214 there are early increases to high Picea values and later declines. With this approach an

215 advance/increase can be seen but not a retreat/decrease. Furthermore, in western and northern

216 Alaska, a few points influence contours over wide areas. We therefore also plotted a series of

217 time-slice maps from $15 \mathrm{kyr}$ BP to present showing contours for the following ranges of

218 pollen values: $>1 \%<5 \%$; $>5 \%<20 \%$; $>20 \%$. The maps include changing coastline and ice-

219 sheet extent based on Manley (2002) and Dyke et al., (2003), respectively, and they enable

220 reductions in pollen values to be plotted spatially. Finally, we collated reported macrofossil

221 data for the region.

222

223 RESULTS

224 Picea history in eastern Beringia: synthesis 
Genetic constraints on post-glacial boreal tree expansion

$>50-15$ k yr BP

The MIS-3 climate regime should have supported tree growth at least in lowland areas (see above), and while there are relatively few MIS-3 localities, macrofossils and pollen records indicate that both species of spruce were present in the region (Table 2; Figs. 2a and 2b). The youngest recorded pre-LGM macrofossils are dated to $\sim 25 \mathrm{ka} \mathrm{BP}$ (Zazula et al., 2006). In contrast, except for values of $>5 \%$ recorded infrequently at two sites in interior Alaska, LGM records show little evidence of high spruce pollen values, although low values (mostly $<2 \%$ ) are recorded at over 30 sites (see Brubaker et al., 2005; Fig. 2c). There are no reliably dated LGM macrofossil records.

\section{5 kyr BP-present}

The earliest reliable post-LGM macrofossil records are from the far east of the region and date to $\sim 13.3$ and $\sim 11 \mathrm{ka}$ (Table 2; Fig. 3d); two older dates (16.3 and $19.1 \mathrm{ka}$ ) for spruce macrofossils from the same area are considered by Hopkins et al., (1981) as unreliable and the macrofossils as probably redeposited. Two macrofossil records in central Alaska date to 10.9 and $10.3 \mathrm{ka}$, though the older is not a direct date on the fossil (Weber et al., 1981). In western Alaska, a white spruce twig AMS-dated to 9200 ka has been reported from thawlake deposits on northern Seward Peninsula by Wetterich et al., (2012). Today this region lies beyond the range spruce, although spruce currently grows on the southeastern Seward Peninsula (Fig. 3). In addition, Fig.2d shows two Picea pollen records ( $\sim 13$ kyr old) in far western Alaska (Colinvaux 1981; Hunt et al., 2013).

The GIS mapping begins at $15 \mathrm{kyr} \mathrm{BP}$ as there are too few sites prior to this to use the threshold mapping approach (Fig.3a-c). The $10 \%$ pollen limits approximate to the modern limits of spruce in the region, which agrees with previous observations (Anderson and Brubaker, 1994). It is important to bear in mind the maps are not migration or distribution 
Genetic constraints on post-glacial boreal tree expansion

maps; they merely summarize the available information on spatial patterns of initial population increase. Southwest Alaska lacks sites, and in this area the age contours are somewhat distorted by the GIS algorithm. It is clear, however, that thresholds are passed later in western Alaska, and here a majority of sites do not pass the $10 \%$ threshold at any time. Values of 1\% are attained 15-12 kyr BP in NW Canada and interior Alaska and in much of the rest of the region except the far west by $9-8 \mathrm{kyr}$ BP. Single sites form "bullseyes" giving the impression of widespread distribution (see also Brubaker et al., 2005). The $5 \%$ and $10 \%$ maps feature smoother patterns and highlight two regions of relatively early increase: northwest Canada (lower Mackenzie region) and interior Alaska-these approximate to the areas where early macrofossils are recorded. At 5\% and 10\%, only sites in NW Canada pass the threshold before $10 \mathrm{kyr} \mathrm{BP}$, and sites in central interior Alaska pass it between 10 and 8 kyr BP. In Figs. 3a-c, the star marks St Paul Island (Colinvaux 1981); here Picea values of as high as $20 \%$ are recorded during the period 12,350-10,700 yr BP (the site was included: compared with exclusion, inclusion affects the $1 \%$ map slightly, but there is no discernable effect on the 5\% and 10\% maps).

The pollen contour maps (Fig. 4) show early (13-12 kyr BP) pollen values $>5 \%$ in NW Canada, possibly before the ice-free corridor is fully open, and values of $>1 \%$ over much of eastern Alaska. At $10 \mathrm{kyr}$ BP the values are between 5 and $20 \%$ over eastern half of the region, with the $>20 \%$ area only in the far NW of the region. Between 10 and $7 \mathrm{kyr}$ BP pollen values decrease in NW Canada, while values $>20 \%$ occur in the eastern interior of the study area. After $7 \mathrm{kyr}$ BP pollen values gradually increase westward. The spatial development of the $>20 \%$ contour likely reflects the mid- and late-Holocene increase and westward expansion of the second species of spruce, Picea mariana. 
Genetic constraints on post-glacial boreal tree expansion

275

276

277

278

279

280

281

282

283

284

285

286

287

288

289

290

291

292

293

294

295

296

297

298

299

\section{DISCUSSION}

Are the eastern Beringia data and maps reliable? They are based on fewer sites than those of Giesecke and Bennett (2004) and thus noisier. The GIS algorithm has limitations, notably that isolated sites exert undue influence on space around them. This is particularly noticeable in SW Alaska, where sites are scarce over a large area. Nevertheless, the maps function to summarize broad spatio-temporal trends in spruce population increase. In particular, both sets of maps show directional trends most clearly at the $10 \%$ pollen threshold, which is consistent with the presence of closed spruce forest, and in both cases is in a broadly eastwest direction.

Some Beringian studies report bulk-sediment ages, which can be older than AMS ages at the same level due to incorporation of old carbon from catchments (Abbott and Stafford, 1999). Where possible we checked records with bulk dates against new (repeat) studies. For example, the notable early spruce rise at Hanging Lake, NW Canada (Cwynar 1982) is retained in the AMS chronology of Kurek et al., (2009).

\section{Comparison of patterns of palaeodata in Scandinavia and eastern Beringia}

A comparison of the two regions reveals both similarities and differences. In Scandinavia the expansion of populations follows a clear east-west trajectory over millennia. In eastern Beringia there are early focussed expansions in the far northeast and central regions, a subsequent filling-in of higher values in these areas, then a more clearly directional westward expansion in the later Holocene.

Nevertheless, in Scandinavia, scattered macrofossil localities record spruce presence in places and at times that complicate a simple model of time-transgressive in-migration that might be inferred from large-scale pollen patterns alone. There is a significant temporal gap between the earliest dated macrofossils, which indicate that small populations of spruce were 
Genetic constraints on post-glacial boreal tree expansion

300 already present, and the later, time-transgressive pollen expansion. This disparity led

301 Kullman (2008) to suggest that pollen records need to be re-evaluated. Do low counts

302 conventionally referred to long-distance transport indicate local presence? More

303 provocatively, is the pollen record incapable of reflecting more widespread populations? Low

304 (or no) pollen production is possible under sub-optimal growth conditions (Hicks, 2006), but

305 this is not likely to be the case when large, widespread populations are present as, by

306 definition, these indicate suitable conditions for reproduction. Thus palynological theory

307 suggests the most parsimonious explanation for the pollen and macrofossil observations is

308 that the Scandinavian early post-glacial period was characterized by small, scattered

309 populations that persisted in sub-optimal conditions at the onset of the interglacial climatic

310 regime. Some of these populations may possibly have been LGM survivors, others probably

311 represent founder events preceding Holocene expansion (Geisecke and Bennett 2004;

312 Kullman 2008).

313 In eastern Beringia both species of spruce were present until the LGM. Low levels of

314 spruce pollen at a majority of sites in ice-free parts of the region dated to the LGM suggest

315 small populations of one or both species (not determined) may have persisted. If so, given a

316 climate substantially more arid than present (Hopkins 1982), trees probably only occurred in

317 highly favourable azonal sites, for example, on or at the base of south-facing slopes, which

318 generated sufficient growing degree-days but where soil conditions were relatively moist,

319 such as drainage gullies or river floodplains. As such, the region would have contained

320 refugia that were scattered and possibly ephemeral (in the case of dynamic floodplain

321 surfaces).

A simple in-migration model is even less well supported in eastern Beringia, where spruce was arguably present in the lower Mackenzie region prior to the opening of the

324 northern portion of the ice-free corridor (Figs. 3 and 4). The existence of in-situ survivors is 
Genetic constraints on post-glacial boreal tree expansion

325

326

327

328

329

330

331

332

333

334

335

336

337

338

339

340

341

342

343

344

345

346

347

348

349

indirectly supported by the fact that the youngest pre-LGM macrofossil records are recorded in the east (Table 2; Fig. 2b), where the earliest rise in pollen values is seen. However, both the oldest post-LGM macrofossils, dated to 13.0 ka, (Table 2; Fig. 2d) and broad-scale multi-millennial pollen patterns are also consistent— - just—with dispersal from the south east through the opening ice-free corridor, assuming extremely fast migration. As of yet, genetic data that might address this dilemma are not reported for this region.

The maps also show populations increasing relatively early (at $10 \mathrm{kyr} \mathrm{BP}$ ) in the Alaskan interior. This expansion is noticeably later than that in NW Canada and could be explained by either dispersal from the east preceded by founder events (compare Fig.1 and Fig.3) or in situ expansion of extant populations. Genetic studies indicate the probable occurrence of local ancestral populations in eastern Beringia, although strong Holocene gene flow has also occurred, and the occurrence of these local haplotypes in central Alaska lends support to the latter explanation (Anderson et al., 2006; 2011).

In the far west of eastern Beringia, pollen of Picea is recorded during late-glacial ( 13-11 kyr BP) from St. Paul Island on the Bering Land Bridge (Colinvaux, 1981; Figs. 2 and 3). The ages are based on bulk sediment dates and thus slightly questionable, but the better dated later part of this record (with high pollen influx values) strongly suggests the presence of spruce at the site $\sim 13$ cal yr BP. Hunt et al., (2013) report Picea pollen (1-4\%) dating to 13,000 cal yr BP from the southern Seward Peninsula (Fig. 2); this is associated with Larix pollen (up to 10\%), which would signal the nearby presence of larch trees, as larch pollen is poorly dispersed. Further to the north is the record of a single Picea glauca needle AMS-dated to $~ 9 \mathrm{ka}$ (Wetterich et al., 2011; Fig. 2d). Thus spruce may have survived on portions of the land bridge and then extirpated during the transgression (the slowly westward advancing treeline now lies to the east; see Fig. 3). 
Genetic constraints on post-glacial boreal tree expansion

350 The role of post-glacial environmental constraints

351 The late-glacial and early-Holocene periods saw major climate change at high latitudes

352 (Miller et al., 2010). In both regions summer temperatures increased and maximum

353 temperatures were probably warmer than present, but cold springs linked to enhanced early-

354 Holocene seasonality (Miller et al.,2010; Kaufman et al., 2004), low effective moisture

355 (Barber \& Finney 2000), and thin snow cover could all have constrained spruce growth

356 (Huntley, 1988; Giesecke \& Bennett, 2004; Brubaker et al., 2005).

Holocene sea-level rise likely contributed to the physical and/or climatological demise of any spruce populations in offshore locations and along the modern coasts of both regions.

In Norway, rising eustatic sea-level outpaced isostatic rebound and led to rapid submergence

360 of narrow coastal shelves. Had populations occurred on the shelves (see Parducci et al., 2012), they would in all likelihood have been rapidly extirpated. In western Alaska, the

Bering Sea transgression covered shallow shelves far more slowly (Figure 4). Eventually, though, coasts and islands in a region increasingly dominated by the expanding cold ocean would have experienced cooling in the growing season (Wetterich et al., 2011). For example, according to the pace of transgression (Manley 2002), the land area of St. Paul Island was rapidly reduced and fragmented at the time Picea disappeared from the pollen record (see Fig. 4). Thus, sub-optimal environmental conditions alone may have played a role in delaying spruce population expansion. When genetic constraints are added, the likelihood of expansion from small populations is lessened further.

The fate of populations surviving long periods in diffuse northern refugia evolutionary and phenotypic constraints

373 The conceptual model developed below assesses how genetic constraints interacting with a

374 changing environment may explain the observed patterns. The focus is more on eastern 
Genetic constraints on post-glacial boreal tree expansion

375 Beringia, where the physical and biological chances of LGM survival were greater, but comparisons are made where appropriate with Scandinavia. Genetic constraint is an overlooked factor in discussions of Holocene repopulation dynamics. Davis et al., (2005) expressed surprise that so little attention is given to the potential (or lack thereof) for taxa to adapt to Quaternary climate change. As with founder populations, relict populations are liable to genetic and demographic constraints related to isolation and small population size (Lande 1988; Hampe \& Jump 2011). In contrast, large migrating populations have a deep reservoir of genetic variation, and this can facilitate rapid evolutionary response to changing environments (Davis et al., 2005).

How would genetic constraints act on populations surviving a glacial-interglacial cycle? Any small, pre-Holocene populations were probably derived from the previous period of widespread forest cover during the last interglaciation $~ 125 \mathrm{kyr}$ BP. Subsequent environmental conditions fluctuated but generally worsened for spruce (reduced growingdegree days, increased aridity, and, particularly in Scandinavia, displacement to periglacial locations by ice advance). Populations left behind on favourable sites as the forest fragmented would have initially maintained genetic interchange and replacement of individuals. The earlier part of the last glacial cycle was punctuated by warm intervals lasting from a few centuries to several thousand years, particularly during MIS 3 (Miller et al., 2010), which would have allowed some population recovery/expansion. Climate conditions tended to become more hostile for trees as time went on, and most populations would have become smaller, some eventually extinct. In Beringia, this process culminated in the LGM, the coldest, driest interval (and thus the most inimical to spruce). As

397 populations became small and isolated, they would have lost genetic variation, and hence evolutionary potential, through genetic drift (i.e., the loss of alleles at random because too

399 few offspring are produced in each generation to "sample" all the genetic diversity of the 
Genetic constraints on post-glacial boreal tree expansion

400 previous generation). Small, isolated populations would also have experienced stringent

401 selection that would have further reduced genetic variation. For example, in conditions far

402 from the climate optimum for the species, shifts in traits characterizing photosynthesis and

403 water use may have been favoured, and the capacity for efficient photosynthesis under more

404 typical climatic conditions may have been lost (i.e., evolutionary specialization). In addition,

405 narrow selective optima may also have led to reduced expression of phenotypic plasticity and

406 eventually, in combination with drift and selection, loss of the genetic basis for future

407 plasticity (Scheiner, 1993; Wagner et al., 1997), reducing the capacity for individuals in the

408 population to adjust physiologically to changing climate. This loss of plasticity would also

409 have reduced the opportunities for genetic assimilation in a strongly altered environment (i.e.,

410 it reduced the potential for genetic evolution to maintain a successful phenotype that might

411 arise from initial plasticity in face of new conditions; see Lande, 2009).

412 In addition, recently developed genetic models have shown that fragmented

413 populations occupying disparate environments have limited capacity to exchange beneficial

414 genes successfully. This is because of genetic correlations (linkage disequilibria) between the

415 genes that are beneficial for the dispersed populations and genes that are beneficial in the

416 "mother" environment but deleterious for the dispersed populations (Shiffers et al., 2013).

417 Hence there is a much reduced potential for fragmented populations to respond evolutionarily

418 to changing climatic conditions than is usually assumed. Furthermore, these models also

419 show that, due to divergent local adaptation, small, fragmented sub-populations occupying

420 disjunct, heterogeneous environments, but subject to gene flow, are at risk of demographic

421 collapse with rapid climate change (Schiffers et al., 2013).

In contrast, larger populations migrating into the study regions from further east

423 would have contained far more genetic variation and phenotypic plasticity, allowing a more

424 rapid and effective phenotypic and evolutionary responses to selection, including via genetic 
Genetic constraints on post-glacial boreal tree expansion

425

426

427

428

429

430

431

432

433

434

435

436

437

438

439

440

441

442

443

444

445

446

447

448

assimilation (Lande, 2009). In such a case, sufficient gene exchange would have occurred subsequently for regional haplotypes to still be observable in modern populations, albeit in low proportions, as recorded by contemporary genetic studies (see above). However, given the arguments above, it is unlikely that genetically constrained relictual populations would have generated all the observed forest expansion in Beringia, at least not without considerable gene flow from in-migrating populations.

In Scandinavia, the greatest expansion of the ice sheet came at the end of the glacial period, 25-15 kyr BP, generating a strong spatial constraint on the size of any surviving populations. Similar genetic constraints would have applied to these populations. It is possible that spatial and temporal dynamism of the ice sheet allowed northern populations present in MIS-3 to persist surprisingly long and even contribute to the Holocene gene pool. If so, it is unlikely they were centrally ancestral to the modern forest, because both the genetics and the pollen-based east-west pattern of expansion are strongly consistent with the spread of a large in-migrating population from central Europe.

\section{CONCLUSION}

It seems likely that the differences in evolutionary response to major climate changes shown by small populations compared with large ones, particularly for organisms with long generation times such as trees, are currently greatly underestimated, and inferences about past processes of population expansion based on observed characteristics of modern populations plus the occurrence of macrofossils may be misleading. New genomic approaches to analysing contemporary populations and the ability to extract mitochondrial DNA from fossil material such as pollen may help further distinguish among the roles of refugial, relictual and founder populations in the response of late-Quaternary trees to climate change. Meanwhile, 
Genetic constraints on post-glacial boreal tree expansion

449 caution is desirable when making inferences about the role of small, refugial populations in 450 large-scale range expansions.

\section{Acknowledgements}

453 We thank Mark Dover of the Southampton Cartographic Unit for GIS analysis and creation 454 of Figures 3 and 4 . We are greatly indebted to Thomas Giesecke for the originals of Figure 1 455 and his thoughtful reviews of earlier versions of this article. Inger Alsos also provided helpful comments on the manuscript.

\section{REFERENCES}

Abbott, M.B. and Stafford, T.W. (1996). Radiocarbon Geochemistry of ancient and modern lakes Arctic lakes, Baffin Island. Quaternary Research, 45, 300-311.

Anderson, P.M. and Brubaker, L.B. (1994). Vegetation history of Northcentral Alaska - A mapped summary of late-Quaternary pollen data. Quaternary Science Reviews 13, 7192.

Anderson, P. M., Edwards, M. E. \& Brubaker, L. B. (2004) Results and paleoclimate implications of 35 years of paleoecological research in Alaska. The Quaternary Period in the United States. Developments in Quaternary Science (ed. by A. E. Gillespie, S. C. Porter \& B. F. Atwater), pp. 427-440. Elsevier, New York.

Anderson, L. L., Hu, F.-S., Nelson, D. M., Petit, R. J., \& Paige, K. N. (2006) Ice-age endurance: DNA evidence of a white spruce refugium in Alaska. Proceedings of the Heredity, 102, 207-216. 
Genetic constraints on post-glacial boreal tree expansion

474 Barber, V.A., \& Finney, B.P. (2000) Late Quaternary paleoclimatic reconstructions for interior Alaska based on paleolake-level data and hydrologic models. Journal of Paleolimnology 24, 29-41.

Barber, V. A., Juday, G. P., \& Finney, B. P. (2000) Reduced growth of Alaskan white spruce in the twentieth century from temperature-induced drought stress. Nature, 405, 668673.

Bennett, K. D. \& Provan, J. (2008) What do we mean by 'refugia'? Quaternary Science Reviews 27, 2449-2455.

Birks, H. J. B. \& Willis, K. J. (2008) Alpines, trees, and refugia in Europe. Plant Ecology \& Diversity, 1, 147-160.

Birks, H. H., Larsen, E. \& Birks H. J. B. (2005) Did tree-Betula, Pinus and Picea survive the 485 last glaciation along the west coast of Norway? A review of the evidence, in light of Kullman (2002). Journal of Biogeography, 32, 1461-1471.

Brubaker, L. B., Anderson, P. A., Edwards M. E., \& Lozhkin, A.V. (2005) Beringia as a glacial refugium for boreal trees and shrubs: New perspectives from mapped pollen data. Journal of Biogeography, 32, 833-848.

Colinvaux, P. A. (1981) Historical ecology in Beringia: the south land bridge coast at St. Paul Island. Quaternary Research, 16, 18-36.

Cwynar, L.C. 1982. A late-Quaternary history from Hanging Lake, northern Yukon. Ecological Monographs 52, 1-24.

Danzeglocke, U., Jöris, O., \& Weninger, B. (2013) CalPal-2007 online. http://www.calpalonline.de/, accessed 2012-5-10 and 2013-8-31.

Davis, M. B. (1981) Quaternary history and the stability of forest communities. Forest 
Genetic constraints on post-glacial boreal tree expansion

499 Davis, M. B., Shaw, R. G. \& Etterson, J. R. (2005) Evolutionary responses to changing 500 climate. Ecology, 86, 1704-1714.

501

Dyke, A S; Moore, A; \& Robertson, L. (2003) Deglaciation of North America; Geological Survey of Canada, Open File 1574; 2 sheets; 1 CD-ROM, doi:10.4095/214399.

Dyke, A. S. (2004) An outline of North American deglaciation with emphasis on central and northern Canada. Quaternary Glaciations-Extent and Chronology, Part II (ed. by J. Ehlers and P. L. Gibbard), pp. 373-424. Elsevier, New York.

Feurdean, A., Bhagwat, S.A., Willis, K.J., Birks, H.J.B., Lischke, H., Hickler, T. (2013) Tree Migration-Rates: Narrowing the Gap between Inferred Post-Glacial Rates and Projected Rates. PLOS ONE 8, e71797, DOI: 10.1371/journal.pone.0071797.

Giesecke, T. \& Bennett, K. D. (2004) The Holocene spread of Picea abies (L.) Karst. in Fennoscandia and adjacent areas. Journal of Biogeography, 31, 1523-1548.

Giesecke, T. 2005a. Moving front or population expansion: How did Picea abies (L.) Karst. become frequent in central Sweden? Quaternary Science Reviews 24, 2495-2509.

Giesecke, T. 2005b. Holocene forest development in the central Scandes Mountains. Vegetation History and Archaeobotany 14, 133-147.

Hampe, A. \& Jump, A. S. (2011) Climate relicts: past, present, future. Annual Review of Ecology, Evolution, and Systematics, 42, 313-33.

Hampe, A. \& Petit, R. J. (2005) Conserving biodiversity under climate change: the rear edge matters. Ecology Letters, 8, 461-467.

Helmens, K. F. \& Engels, S. (2010) Ice-free conditions in eastern Fennoscandia during early Marine Isotope Stage 3: lacustrine records. Boreas, 39, 399-409.

Hicks, S. (2006) When no pollen does not mean no trees. Vegetation History and Archaeobotany, 15, 253-261. 
Genetic constraints on post-glacial boreal tree expansion

523 Hopkins, D. M. (1982) Aspects of the paleogeography of Beringia during the late Pleistocene. Paleoecology of Beringia (ed. by D. M. Hopkins, J. V. Matthews, Jr., C. E. Schweger, and S. B. Young), pp. 3-28. Academic Press, New York.

Hopkins, D. M., Smith, P. A. \& Matthews, J. V., Jr. (1981) Dated wood from Alaska and the Yukon: implications for forest refugia in Beringia. Quaternary Research, 15, 217249.

Hunt, S., Yu, Z. \& Jones, M. (2013) Lateglacial and Holocene climate, disturbance and permafrost peatland dynamics on the Seward Peninsula, western Alaska. Quaternary Science Reviews 63, 42-58.

Huntley, B. (1988) Europe. Vegetation History (ed. by B. Huntley and T. Webb III) , pp 341383. Kluwer Academic Publishers, Dordrecht.

Kaufman, D. S., Ager, T. A., Anderson, N. J., Anderson, P. M., Andrews, J. T., Bartlein, P. J., Brubaker, L. B., Coats, L. L., Cwynar, L. C., Duvall, M. L., Dyke, A. S., Edwards, M. E., Eisner, W. R., Gajewski, K., Geirsdottir, A., Hu, F.-S., Jennings, A. E., Kaplan, M. R., Kerwin, M. W., Lozhkin, A. V., MacDonald, G. M., Miller, G. H., Mock, C. J., Oswald, W. W., Otto-Bliesner, B. L., Porinchu, D. F., Ruhland, K., Smol, J.P., Steig, E. P. \& Wolfe, B. B. (2004) Holocene thermal maximum in the western Arctic (0-

544 Kullman, L. (2008) Early postglacial appearance of tree species in northern Scandinavia: review and perspective. Quaternary Science Reviews, 27, 2467-2472. 
Genetic constraints on post-glacial boreal tree expansion

546 Kurek, J., Cwynar, L.C. \& Vermaire, J.C. (2009) A late Quaternary paleotemperature record from Hanging Lake, northern Yukon Territory, eastern Beringia. Quaternary Research 72, 246-257.

Lande, R. (1988) Genetics and demography in biological conservation. Science, 241, 14551460.

Lande, R. (2009). Adaptation to an extraordinary environment by evolution of phenotypic plasticity and genetic assimilation. Journal of Evolutionary Biology 22, 1435-1446.

Mclachlan, J. S., Clark, J. S. \& Manos, P. S. (2005) Molecular indicators of tree migration capacity under rapid climate change. Ecology, 86, 2088-2098.

Magri, D. (2008) Patterns of post-glacial spread and the extent of glacial refugia of European beech (Fagus sylvatica). Journal of Biogeography, 35, 450-463.

Manley, W.F., 2002, Postglacial Flooding of the Bering Land Bridge: A Geospatial animation: INSTAAR, University of Colorado, v1, http://instaar.colorado.edu/QGISL/bering_land_bridge.

Miller, G. H., Brigham-Grette, J., Alley, R. B., Anderson, L., Bauch, H. A., Douglas, M., Edwards, M. E., Elias, S. A., Finney, B., Fitzpatrick, J. J., Funder, S. V., Herbert, T. D., Hinzman, L., Kaufman, D., MacDonald, G. M., Polyak, L., Robock, A., Serreze, M., Smol, J., Spielhagen, R., White, J. W. C., Wolfe, A. P., \& Wolff, E.W. (2010)

Oberg, L. \& L. Kullman. (2011). Ancient Subalpine Clonal Spruces (Picea abies): Sources of Postglacial Vegetation History in the Swedish Scandes. Arctic 64, 183-196. Bennett, K. D., Haile, J., Matetovici, I., Suyama, Y., Edwards, M. E., Andersen, K., Rasmussen, M., Boessenkool, S., Coissac, E., Brochmann, C., Taberlet, P., Houmark- 
Genetic constraints on post-glacial boreal tree expansion Willerslev, E. (2012a) Glacial survival of boreal trees in northern Scandinavia. Science, 335, 1083-1086.

Paus, A., G. Velle, \& Berge, J. (2011) The Lateglacial and early Holocene vegetation and environment in the Dovre mountains, central Norway, as signalled in two Lateglacial nunatak lakes. Quaternary Science Reviews, 30, 1780-1796.

Scheiner, SM. (1993). Genetics and evolution of phenotypic plasticity. Annual Review of Ecology and Systematics 24, 35-68.

Schiffers, K., E.C. Bourne, S. Lavergne, W. Thuiller,\& J.M.J. Travis. (2013). Limited evolutionary rescue of locally adapted populations facing climate change. Philosophical Transactions of the Royal Society B-Biological Sciences 368, 1610 (Article Number: 20120083, DOI: 10.1098/rstb.2012.0083).

Stewart, J. R. A, Lister, A., Barnes, I., \& Dalén, L. (2009) Refugia revisited: individualistic responses of species in space and time. Proceedings of the Royal Society B, 277, 661671.

Svenning, J-C., Normand, S. and Skov, F. 2008.Postglacial dispersal limitation of widespread forest plant species in nemoral Europe. Ecography 31, 316-326.

Tollefsrud, M. M., Kissling, R., Gugereli, F., Johnsen, O., Skroppa, T., Cheddadi, R., Van der Knapp, W. O., Lataaowa, M., Terhurne-Berson, R., Litt, T., Geburek, Y., Brochmann, C., \& Sperisen, C. (2008) Genetic consequences of glacial survival and postglacial colonization in Norway spruce: combined analysis of mitochondrial DNA and fossil pollen. Molecular Ecology, 17, 4134-4150.

Tollefsrud, M. M, Sonstebo, J. H., Brochmann, C., Johnsen, O., Skroppa, T. \& Vendramin, G. G. (2009) Combined analysis of nuclear and mitochondrial markers provide new insight into the genetic structure of North European Picea abies. Heredity, 102, 549562. 
Genetic constraints on post-glacial boreal tree expansion

597 Tzedakis, P.C., Emerson, B.C. and Hewitt, G.M. (2013). Cryptic or mystic? Glacial tree refugia in northern Europe. Trends in Ecology and Evolution 28, 696-704.

Wagner, G.P., G. Booth, \& H.C. Bagheri (1997). A population genetic theory of canalization. Evolution 51, 329-347.

601 Weber, F.R., Hamilton, T.D., Hopkins, D.M., Repenning, C.A. \& Haas, S. 1981. Canyon

602 Creek: A Late Pleistocene Vertebrate Locality in Interior Alaska. Quaternary

603 Research, 16, 167-180.

604

605

Wetterich, S., Grosse, G., Schirrmeister, L., Andreev, A. A., Bobrov, A. A., Kienast, F., Bigelow, N. H., \& Edwards, M. E. (2011) Late Quaternary environmental and landscape dynamics revealed by a pingo sequence on the northern Seward Peninsula, Alaska. Quaternary Science Reviews, 39, 26-44.

Wohlfarth, B., Björk, S., Funder, S., Houmark-Nielsen, M., Ingolfsseon, O., Lunkka, J-P., 609

610 Mangerud, J., Saarnisto, M. \& Vorren, T. (2008) Quaternary of Norden. Episodes, 31,

Zazula, G. D., Telka, A. M., Harington, C., Schweger, C. E. \& Mathewes, R. W. (2006) New spruce (Picea spp.) macrofossils from Yukon Territory: implications for Late Pleistocene refugia in Eastern Beringia. Arctic, 59, 391-400.

Additional references to data sources may be found at the end of Appendix S1 at [URL]

615

SUPPORTING INFORMATION

617

Appendix S1. List of sites used in the eastern Beringia pollen mapping and related references.

618

619

620

\section{BIOSKETCHES}


Genetic constraints on post-glacial boreal tree expansion

621 Mary Edwards is interested in, among other things, the biogeography, ecology and

622 palaeoecology of northern regions and is currently fascinated by the heated debate

623 surrounding the implications of northern refugia.

624

625 Scott Armbruster is interested in the evolutionary genetics and ecology of

626 plant adaptation to the biotic environment and in the role of microclimatic

627 heterogeneity and competition in plant-community assembly.

628 Scott Elias is principally interested in Quaternary insect fossils, with a focus on the regions

629 on both sides of the Bering Strait, and in the integration of insect-based climate

630 reconstructions with other proxy data.

631

632

633

634

635

636

637

638

639

640

641

642

643

644

645

Table 1 
Genetic constraints on post-glacial boreal tree expansion

646 Picea macrofossil records from Scandinavia.

647

\begin{tabular}{|l|l|l|l|}
\hline Site Name & Date (cal yr & Date ${ }^{\mathbf{1 4}} \mathbf{C}$ yr & Source publication \\
\hline Mt Åreskutan & $\mathbf{B P})$ & $\mathbf{B P}$ & \\
\hline Mt Åreskutan & & $11,020 \pm 90$ & Kullman (2002) \\
\hline Mt Åreskutan & & $8640 \pm 60$ & Kullman (2002) \\
\hline Southern Swedish Scandes & $9540-9320$ & $8450 \pm 60$ & Oberg and Kullman (2011) \\
\hline Southern Swedish Scandes & $9530-9380$ & $8490 \pm 70$ & Oberg and Kullman (2011) \\
\hline Southern Swedish Scandes & $9720-9520$ & $8630 \pm 60$ & Oberg and Kullman (2011) \\
\hline Southern Swedish Scandes & $9120-8660$ & $8050 \pm 70$ & Oberg and Kullman (2011) \\
\hline Southern Swedish Scandes & $9270-9000$ & $8140 \pm 60$ & Oberg and Kullman (2011) \\
\hline
\end{tabular}

648

649 
Genetic constraints on post-glacial boreal tree expansion

650

651

652

653

654

\section{Table 2}

Picea macrofossil records from eastern Beringia. The sites are shown on Fig. 2. Sites labelled (4) on map (b) are located close together. *Original dates that were calibrated for this study. **Sleet Lake date is an estimate only, derived from digitizing the pollen/macrofossil diagram and assigning an arbitrary error to the estimated radiocarbon age that was calibrated.

\begin{tabular}{|c|c|c|c|c|}
\hline Site Name & Date cal yr BP & $\begin{array}{l}\text { Date }{ }^{14} \mathrm{C} \text { yr } \\
\text { BP }\end{array}$ & $\begin{array}{l}\text { Location } \\
\text { on Fig.2 }\end{array}$ & Source publication \\
\hline Isabella Basin & $38,994 \pm 2843^{*}$ & $34900 \pm 2950$ & (a) 1 & Hopkins et al., (1981) \\
\hline Mayo Village & $42697 \pm 1024$ & $38100 \pm 1330$ & (a) 2 & Zazula et al., (2006) \\
\hline Bluefish River & $29328 \pm 469$ & $24530 \pm 180$ & (b) 3 & Zazula et al., (2006) \\
\hline Quartz Creek & $\begin{array}{l}30846 \pm 386 \\
30891 \pm 362\end{array}$ & $\begin{array}{l}25800 \pm 240 \\
25800 \pm 240\end{array}$ & (b) 4 & Zazula et al., (2006) \\
\hline $\begin{array}{l}\text { Last Chance } \\
\text { Creek }\end{array}$ & $31122 \pm 364$ & $26280 \pm 210$ & $\begin{array}{l}\text { (b) } 4 \\
\text { (overlaid) }\end{array}$ & Zazula et al., (2006) \\
\hline Sixtymile River & $31009 \pm 388$ & $26080 \pm 300$ & $\begin{array}{l}\text { (b) } 4 \\
\text { (overlaid) }\end{array}$ & Zazula et al., (2006) \\
\hline Mayo Village & $33587 \pm 555$ & $29600 \pm 300$ & $\begin{array}{l}\text { (b) } 4 \\
\text { (overlaid) }\end{array}$ & Zazula et al., (2006) \\
\hline Twin Lakes & $13391 \pm 181^{*}$ & $11500 \pm 160$ & (d) 6 & Hopkins et al., (1981) \\
\hline Sleet Lake** & $11025 \pm 166$ & $9700 \pm 100$ & (d) 5 & Spear (1993) \\
\hline Whitefish Lake & $10849 \pm 241$ & $9530 \pm 170$ & (d) 7 & Hopkins et al., (1981) \\
\hline Canyon Creek & $10965 \pm 207$ & $9640 \pm 155$ & (d) 8 & Weber et al., (1981) \\
\hline Tangle Lakes & $10304 \pm 88$ & $9100 \pm 80$ & (d) 9 & Hopkins et al., (1981) \\
\hline Kitluk Pingo & $9012-9562$ & $8250 \pm 100$ & (d) 10 & Wetterich et al., (2011) \\
\hline
\end{tabular}


Genetic constraints on post-glacial boreal tree expansion

\section{Figure Captions}

657 Figure 1. Three maps of the time of first expansion of pollen percentages of Picea abies to a 658 threshold value. Maps (a-c) are for 1\%, 5\% and 10\% thresholds, respectively. Dots, squares 659 and triangles mark sites used in the interpolations (see Giesecke \& Bennett [2004] for 660 complete details). Dark line marks the limits of $P$. abies. Figure reproduced, with permission, 661 from Giesecke and Bennett (2004).

662

663 Figure 2. Pollen (circles) and macrofossil records (triangles) of Picea in eastern Beringia. 664 (a) - records from mid marine isotope stage 3 (MIS-3), 50-35 kyr BP; (b) - records from late 665 MIS-3, 35-24 kyr BP; (c) - records from the last glacial maximum (LGM), 24-15 kyr BP; (d) 666 - late-glacial and early-Holocene macrofossils (15-9 kyr BP). Numbers in triangles refer to 667 macrofossil site details provided in Table 2. Site 4 (Fig. 2b) represents four different localities in the same area. The filled circles in (d) represent Picea pollen values from Calaloq Lake, St. Paul Island (Colinvaux, 1981) and southern Seward Peninsula (Hunt et al., 2013). On (a)

670 "SP" denotes the Seward Peninsula and "LM" the lower Mackenzie region, as mentioned in 671 the text.

672

673 Figure 3. The times at which pollen values of $1 \%, 5 \%$, and $10 \%$ are reached in eastern

674 Beringia is shown by maps a-c, respectively. Black dots are sites that reach the threshold;

675 white dots are sites not reaching the threshold (note in Fig. 3c these have a light grey tone to 676 help distinguish against background). Current Picea distribution is shown by the solid line. 677 The star indicates St. Paul Island (Colinvaux, 1981).

678

679 Figure 4. Eight maps for 1000-yr time slices showing contours for the following pollen 680 percentage ranges: $>1-5 ;>5<20$; and $>20$. The format enables both increases and declines in 
Genetic constraints on post-glacial boreal tree expansion

681 pollen abundance over time to be visualized. Also shown: the Bering Sea post-glacial 682 transgression after Manley (2002) and extent of ice sheets after Dyke et al., (2003).

683 
Figure 1
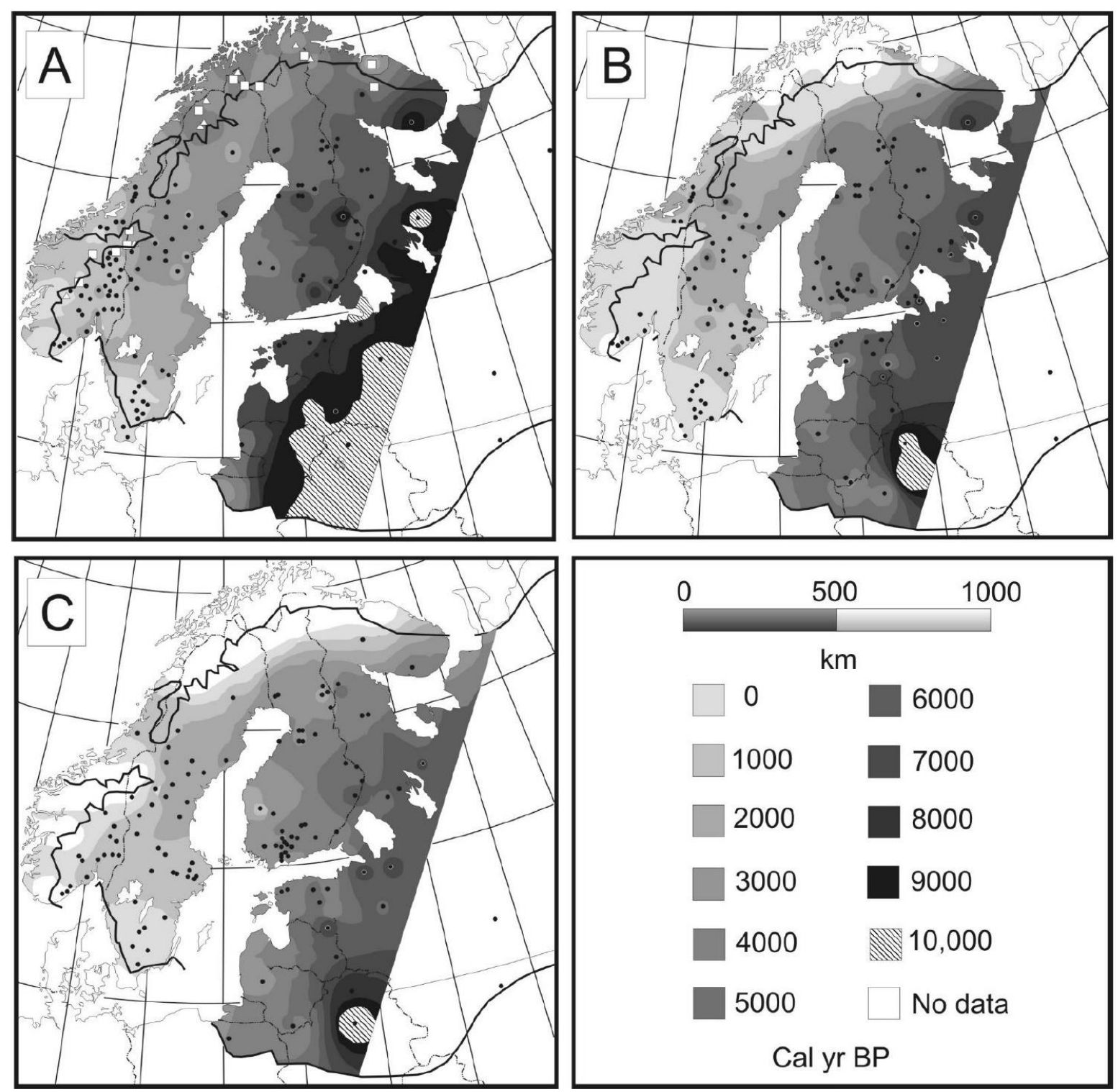

685

686

687

688

689

690

691

692

693 
Genetic constraints on post-glacial boreal tree expansion

694 Figure 2
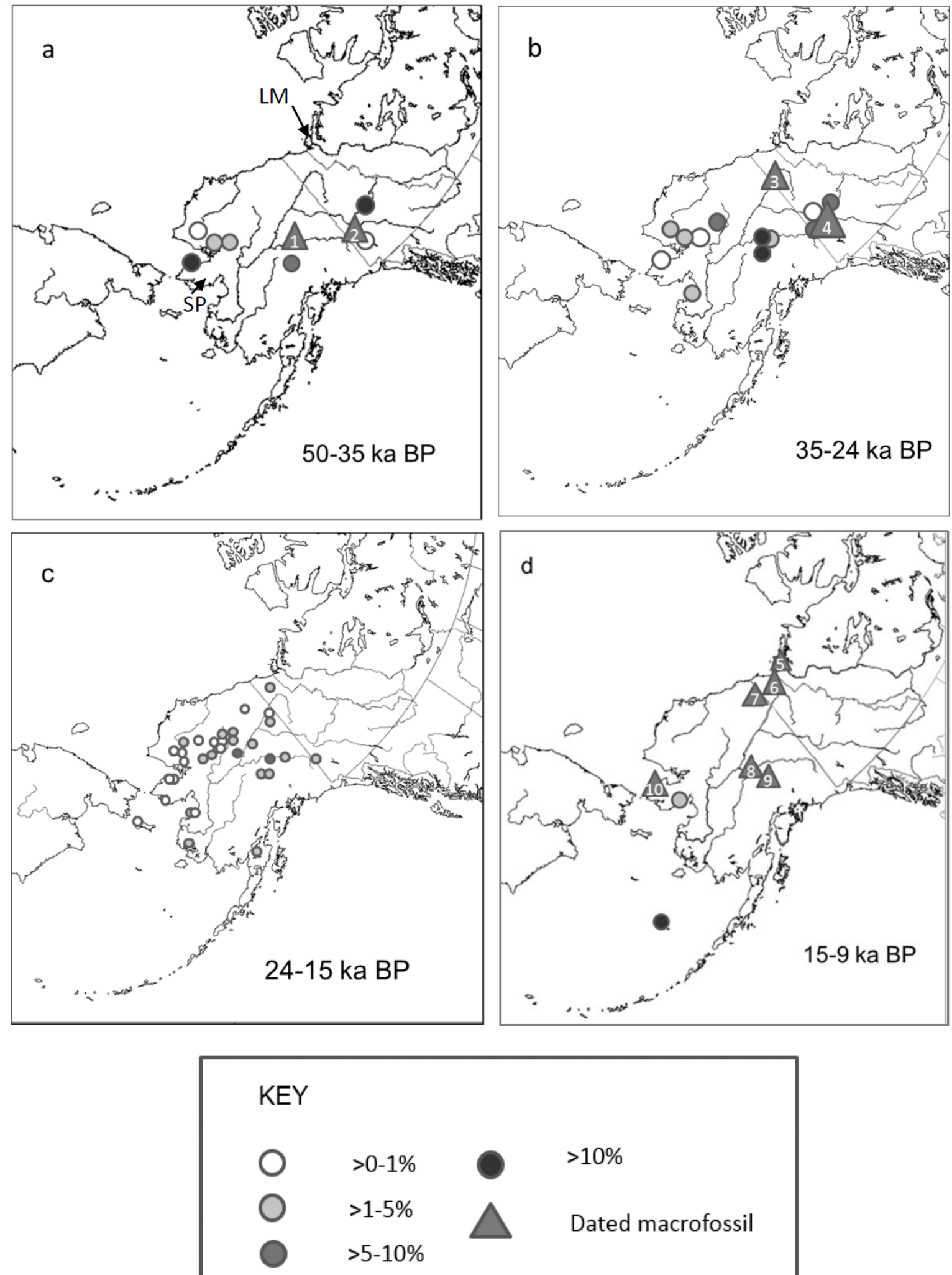

695 
Genetic constraints on post-glacial boreal tree expansion

697

Figure 3

698

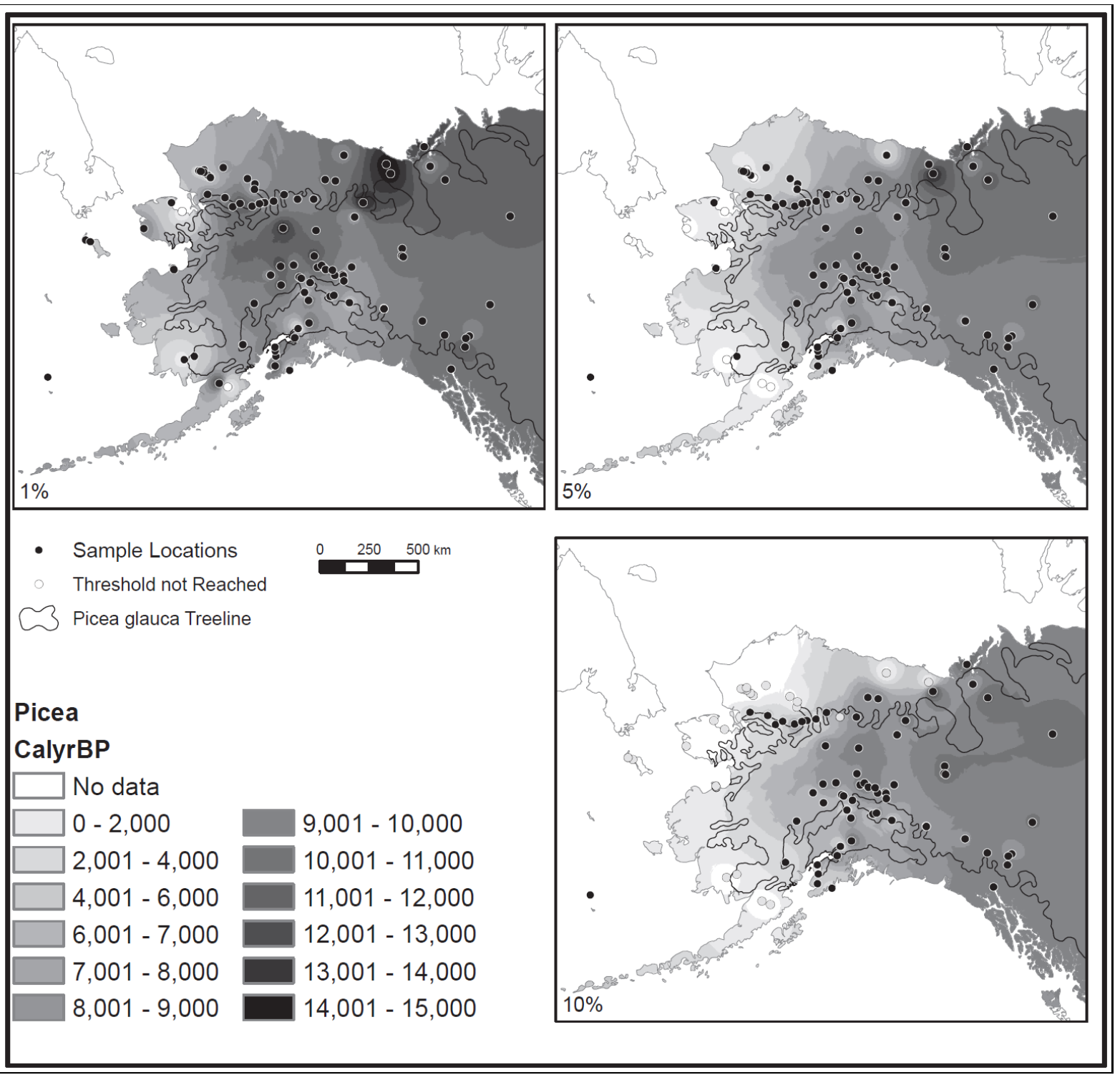

700

701

702 
Genetic constraints on post-glacial boreal tree expansion

Figure 4
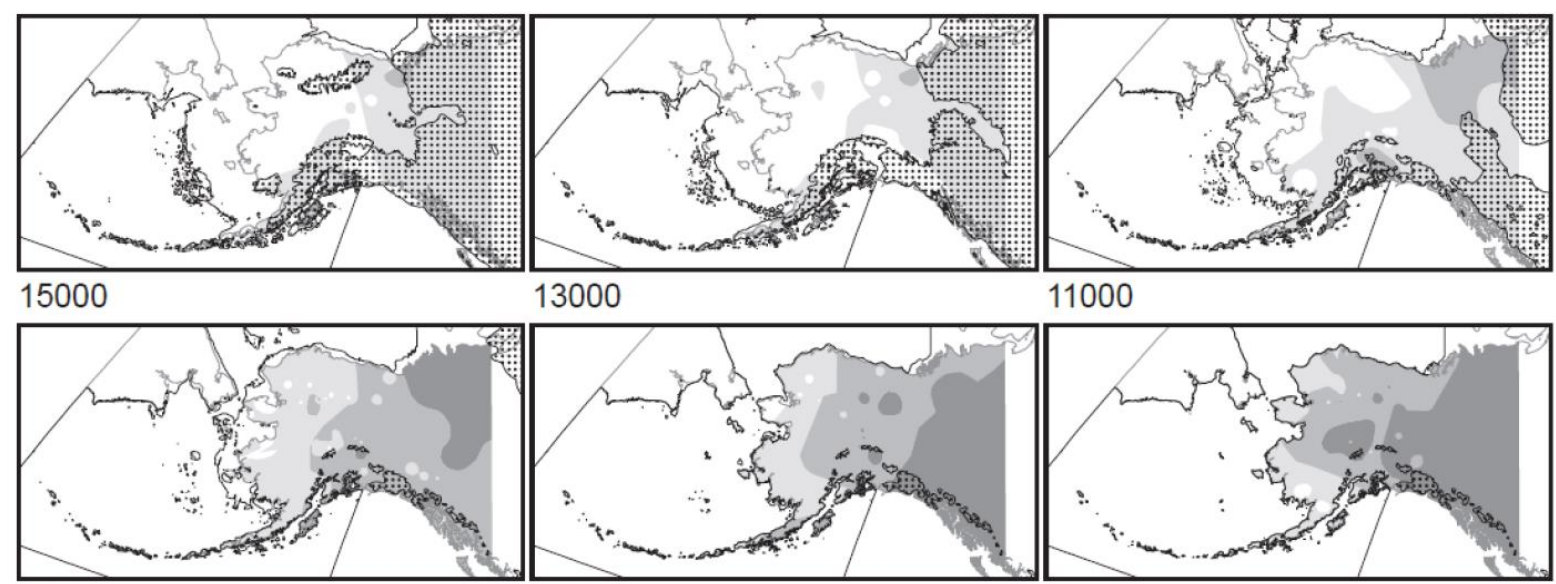

11000

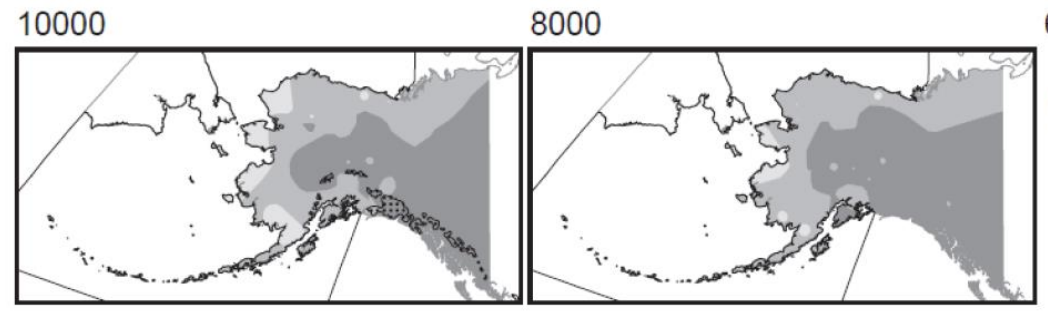

$4000 \quad 0$ CalyrBP

704

December 2013 Cartographic Services: University of Southampton

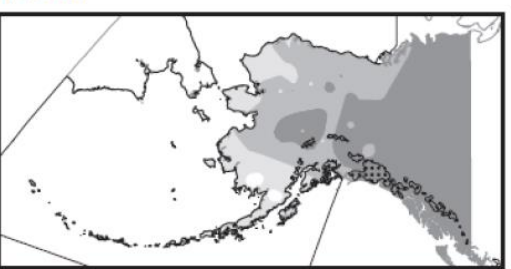

6000

Picea pollen

abundances

$>1$ 清霜 Dyke Glaciation Data

$>5 \square$ Manley Bering Sea Data

$>20$

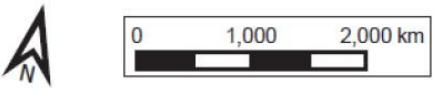

705

706

707

708 